\title{
RIWAYAT PEMBERIAN ASI EKSLUSIF , IMUNISASI DAN PARITAS DENGAN
} STATUS GIZI BADUTA

\section{HISTORY OF EXCLUSIVE BREASTFEEDING, IMMUNIZATION AND PARITY WITH THE NUTRITIONAL STATUS OF TODDLERS}

\author{
Yena Wineini Migang \\ Poltekkes Kemenkes Palangka Raya \\ Jalan G.Obos No30/32 Kota Palangka Raya. Indonesia \\ Email : yenawineini.migang@yahoo.co.id
}

\begin{abstract}
Malnutrition status in baduta is characterized by thin body, less weight compared to age, z-score value $(-3 S D$ S.D $<-2 S D)$. Undernutrition status is at risk of experiencing malnutrition which has the potential to increase morbidity and mortality. Aimed at analyzing the relationship and prevalence ratio $(P R)$ of variable history of exclusive breastfeeding, immunization, and parity with nutritional status of baduta. The subjects of the study were 72 children aged 7-24 months with purposive sampling technique. Cross sectional study design, with chi-square test. The results of the study were that the history of exclusive breastfeeding was related to the nutritional status of underweight, the value of $\rho$ $(0.020<0.05)$, and there was no relationship between the history of immunization, parity and maternal education with the nutritional status of under-five, where the value of $\rho>0.05$. Prevalence Ratio (PR) shows that poor women who are not exclusively breastfed have a 4 times greater risk of experiencing under-nutrition status than those who are exclusively breastfeeding.
\end{abstract}

Keywords: Exclusive breastfeeding; Immunization; Parity; Nutritional Status; Toddlers

\begin{abstract}
ABSTRAK
Status gizi kurang pada baduta ditandai dengan badan kurus, kurangnya berat badan dibandingkan dengan usia, nilai $z$-score (-3 SD S.D $<-2$ SD). Status gizi kurang beresiko mengalami gizi buruk yang potensial meningkatkan morbiditas dan mortalitas. Bertujuan menganalisa hubungan dan prevalensi ratio (PR) variabel riwayat pemberian ASI Ekslusif, imunisasi, dan paritas dengan status gizi baduta. Subyek penelitian 72 anak baduta usia 7-24 bulan dengan tehnik purposive sampling. Desain studi cross sectional, dengan uji chi-square. Hasil penelitian riwayat pemberian ASI Ekslusif berhubungan dengan status gizi baduta, nilai $\rho(0,020<0,05)$, dan tidak ada hubungan riwayat imunisasi, paritas dan pendidikan ibu dengan status gizi baduta, dimana nilai $\rho>0,05$. Nilai PR 4,000 pada variable ASI ekslusif dengan status gizi baduta, artinya baduta yang tidak ASI ekslusif beresiko 4 kali lebih besar untuk mengalami status gizi kurang dibanding baduta yang mendapatkan ASI ekslusif.
\end{abstract}

Kata kunci: ASI ekslusif; Imunisasi; Paritas; Status Gizi; Baduta

\section{PENDAHULUAN}

Penyakit infeksi sangat mempengaruhi status gizi pada baduta, karena itu pemerintah membuat program intervensi gizi spesifik yang salah satunya adalah dengan pemberian ASI ekslusif dan imunisasi. Capaian imunisasi dasar lengkap untuk Provinsi Kalimantan Tengah tahun 2019 sebesar (74,5\%) lebih tinggi dibandingkan tahun 2018 sebesar $(74,1 \%)$ (1). Kota Palangka Raya merupakan salah satu dari kabupaten yang rendah capaian imunisasi dasar lengkap hanya sebesar (33,3 \%)(1). Cakupan bayi mendapat ASI eksklusif tahun 2019 di Provinsi Kalimantan Tengah sebesar $(51,4 \%)$ lebih tinggi dibandingkan tahun 2018 sebesar (23,3\%). Berdasarkan data profil kesehatan Kota Palangka Raya tahun 2020, angka cakupan ASI Eksklusif di tahun 2018 di angka( 41,69\%) kemudian naik sedikit di tahun 2019 yang mencapai $(49,25 \%)$, masih jauh dari target yang seharusnya (90\%)(2). Demikian juga jumlah paritas merupakan salah satu faktor yang menyebabkan kurangnya kemampuan keluarga untuk memberikan pola asuh yang tepat bagi baduta, kemampuan ekonomi berhubungan dengan jumlah anggota keluarga (3).Oleh karena itu, salah satu program keluarga berencana (KB), adalah membatasi jumlah anak dengan menggunakan kontrasepsi 
jangka panjang, seperti IUD dan implant untuk mecegah kehamilan bagi.(4)

Faktor terjadinya stunting pada anak yaitu jumlah paritas, dan ini berhubungan dengan ketersediaan kontrasepsi bagi ibu yang ingin mengatur jarak dan jumlah kelahiran(5); (6). Data BKKBN Perwakilan Kalimantan Tengah, persentase tertinggi penggunaan jenis alat kontrasepsi adalah kontrasepsi suntik (60\%), Provinsi Kalimantan Tengah pada tahun 2019 persentase baduta gizi kurang sebesar $(10,1 \%)$ (1). Hal tersebut berbeda jauh dengan hasil Riset Kesehatan Dasar (Riskesdas) diselenggarakan oleh Kementerian Kesehatan tahun 2018, yaitu persentase gizi kurang sebesar (16,9\%). Status gizi baduta di Kota Palangka Raya tahun 2019, menurut data baduta ditimbang ada $(7,02 \%)$, dengan kasus baduta gizi kurang (2,96\%), kasus baduta pendek $(2,27 \%)$ dan kasus baduta kurus (1,13\%) (2). Walaupun persentase baduta yang mengalami masalah status gizi rendah, dibandingkan dengan wilayah lainnya, tapi masih ditemukannya baduta gizi kurang, baduta gizi pendek dan baduta gizi kurus, bila tidak segera di intervensi dan dilakukan upaya preventif maka akan potensial terjadi peningkatan persentase di masa depan.

\section{BAHAN DAN METODE}

Desain penelitian ini adalah studi cross sectional, dengan variabel penelitian riwayat pemberian ASI Ekslusif, imunisasi, paritas dan status gizi baduta. Penelitian dilakukan di Kota Palangka Raya wilayah kerja Puskesmas Pahandut, subyek penelitian adalah keluarga yang memiliki anak baduta usia 7-24 bulan dengan jumlah 72 orang, subyek diperoleh dengan teknik purposive sampling, dengan kriteria inklusi adalah baduta yang diasuh serumah dengan ibu kandung, dn kriteria ekslusi adalah baduta yang mengalami sakit kronis saat penelitian dilakukan. Uji analisa yang digunakan adalah dengan Chi square.

\section{HASIL DAN PEMBAHASAN}

Penelitian ini pada tahun 2020 di Kota Palangka Raya wilayah kerja Puskesmas Pahandut. Bertujuan ingin melihat hubungan dan nilai PR antara variable riwayat pemberian ASI Ekslusif, imunisasi, dan paritas dengan status gizi baduta

\section{Analisis Univariat}

Tabel 1 merupakan analisa univariat pada lima variabel, yaitu status gizi baduta, riwayat pemberian ASI ekslusif, riwayat imunisasi, paritas dan penddikan ibu. Total subyek ada 72 orang. Berdasarkan tabel 1, maka dari 72 subyek terdapat baduta gizi kurang $(29,2 \%)$ dan gizi baik $(70,8 \%)$, dan persentase teringgi untuk riwayat asi ekslusif
(56,9\%), tidak asi ekslusif $(43,1 \$)$, mendapatkan imunisasi lengkap $(80,6 \%)$, dan tidak mendapat imunisasi lengkap $(19,4 \%)$, dan paritas $<3$ orang anak $(69,9 \%)$ sedangkan paritas $\geq 3$ orang $(30,6 \%)$. Pendidikan ibu persentase tertinggi adalah pendidikan dasar $\leq 9$ tahun $(58,3 \%)$ yang sedangkan ibu yang pendidikan lanjut $>9$ tahun $(41,7 \%)$.

Tabel 1 Distribusi Frekuensi Variabel Penelitian

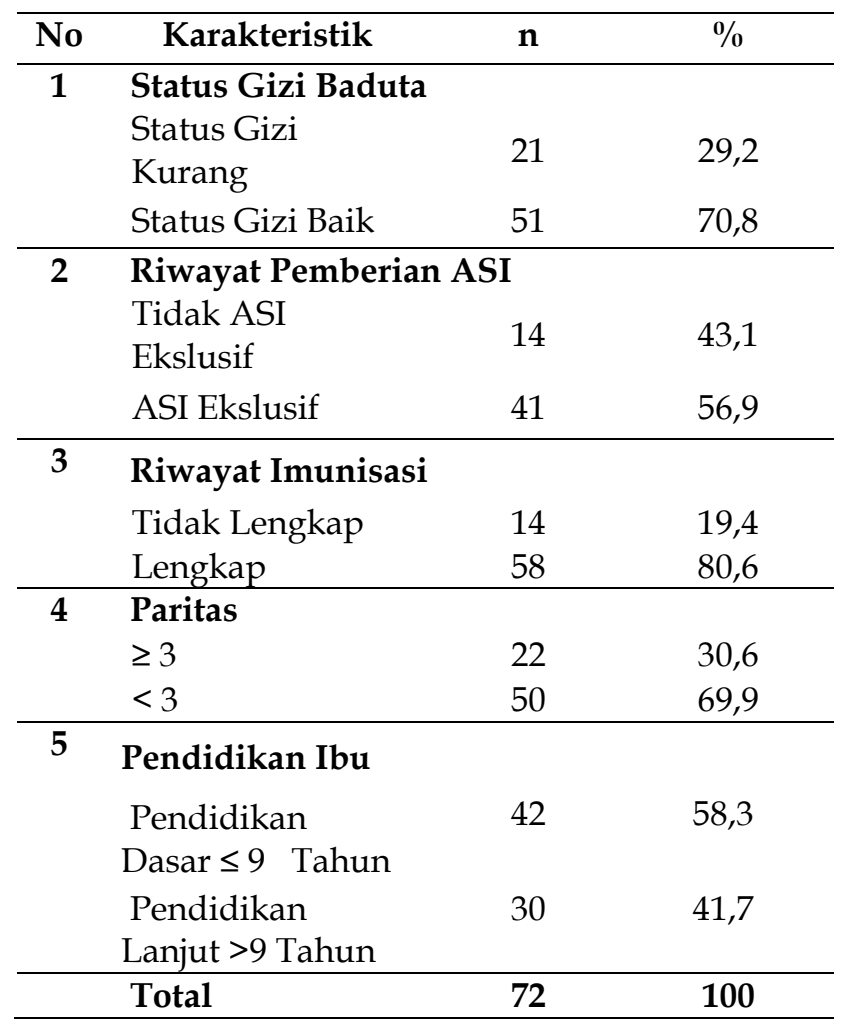

Berdasarkan pengukuran antropometri berat badan dibandingkan usia (BB/U) yang kemudian dianalisa menggunakan aplikasi Anthro WHO maka didapat nilai $Z$ score yang status gizi kurang pada anak usia dibawah lima tahun (-3 SD S.D<-2 SD) dan nilai z score untuk gizi baik (-2 SD S.D 2 SD) bahwa persentase baduta dengan gizi baik lebih banyak. Status gizi berdasarkan BB/U menggambar kecukupan asupan gizi (7), dan juga menggambarkan bahwa baduta jarang mengalami penyakit infeksi, yang salah satu upaya dilakukan adalah dengan membentuk imunitas melakui vaksinasi (8).

Pada penelitian ini subyek di tanyakan apakah telah mendapatkan imunisasi lengkap sebelum usia 12 bulan, sesuai program vaksinasi dasar dari pemerintah yang bertujuan untuk memberikan imunitas pada baduta. Adanya kecukupan gizi saat bayi juga mempengaruhi keadaan imunitas baduta dalam tahap pertumbuhan dan perkembangannya. Salah satu manfaat ASI ekslusif adalah kolostrum yang merupakan faktor pelindung kekebalan tubuh dan faktor pertumbuhan. Kandungan gizi pada ASI 
yang tidak dapat diwakilkan oleh susu formula, seperti adanya kandungan bakteri baik dan enzim yang dapat memperkuat usus serta pencernaan bayi, selain itu zat gizi yang terkandung dalam ASI mudah diserap oleh sistem pencernaan bayi, sehingga bayi dapat mengalami tumbuh kembang secara sempurna sesuai kebutuhan.Paritas merupakan jumlah anak yang hidup ataupun mati (9).

Pendidikan ibu dengan kategori Pendidikan dasar $\leq 9$ tahun merupakan pendidikan yang dihitung dari sekolah dasar sampai tingkat sekolah menengah atas, dan pada penelitian ini $(58,3 \%)$ merupakan subyek yang Pendidikan dasar $\leq 9$ tahun. Pendidikan dapat mempengaruhi wawasan ibu dalam pemberian imunisasi, pemberian ASI ekslusif dan akses layananan kontrasepsi untuk mengatur jumlah paritas (10).

\section{Analisis Bivariat}

Berikut adalah hasil analisa bivariat antara variabel independen (riwayat pemberian ASI ekslusif, riwayat imunisasi, paritas dan pendidikan $\mathrm{ibu}$ ), dengan variabel dependen ( status gizi baduta), analisa menggunakan chi square. Hasil uji statistik bahwa yang memiliki hubungan signifikan adalah riwayat pemberian ASI ekslusif dengan status gizi baduta, dimana nilai $\rho 0,02<0,05$, dan hasil uji statistik tidak ada hubungan antara variabel riwayat imunisasi, paritas dan pendidikan ibu dengan status gizi baduta, dimana nilai $\rho>0,05$. Perhitungan nilai PR dengan pendekatan OR didapat bahwa baduta yang tidak ASI ekslusif beresiko 4 kali lebih besar untuk mengalami status gizi kurang dibanding baduta yang mendapatkan ASI ekslusif.

Tabel 2. Hubungan Status Gizi Baduta, Riwayat Pemberian ASI Ekslusif, Riwayat Imunisasi , Paritas, dan Pendidikan Ibu di Wilayah Kerja Puskesmas Pahandut Kota Palangka Raya

\begin{tabular}{|c|c|c|c|c|c|c|c|c|}
\hline \multirow[t]{3}{*}{ Variabel } & \multicolumn{4}{|c|}{ Status Gizi Baduta } & \multicolumn{2}{|c|}{ Total } & \multirow{3}{*}{$\begin{array}{c}\text { PR } \\
(95 \%)\end{array}$} & \multirow[t]{3}{*}{ P Value } \\
\hline & \multicolumn{2}{|c|}{ Gizi Kurang } & \multicolumn{2}{|c|}{ Gizi Baik } & & & \\
\hline & $\mathbf{n}$ & $\%$ & $\mathbf{n}$ & $\%$ & $\mathbf{n}$ & $\%$ & & \\
\hline \multicolumn{9}{|c|}{ Riwayat Pemberian ASI Ekslusif } \\
\hline Tidak ASI Ekslusif & 14 & 45,2 & 17 & 54,8 & 31 & 100 & \multirow{2}{*}{$\begin{array}{c}4,000 \\
(1,361-11,755)\end{array}$} & \multirow[t]{2}{*}{0,020} \\
\hline ASI Ekslusif & 7 & 17,1 & 34 & 82,9 & 41 & 100 & & \\
\hline \multicolumn{9}{|l|}{ Riwayat Imunisasi } \\
\hline Tidak Lengkap & 4 & 28,6 & 10 & 71,4 & 14 & 100 & \multirow{2}{*}{$\begin{array}{c}1,098 \\
(0,298-4,053)\end{array}$} & \multirow[t]{2}{*}{1,000} \\
\hline Lengkap & 17 & 29,3 & 41 & 70,7 & 58 & 100 & & \\
\hline \multicolumn{9}{|l|}{ Paritas } \\
\hline$\geq 3$ & 6 & 27,3 & 16 & 72,7 & 22 & 100 & \multirow{2}{*}{$\begin{array}{c}0,875 \\
(0,287-2,672)\end{array}$} & \multirow[t]{2}{*}{1,000} \\
\hline$<3$ & 15 & 30,0 & 35 & 70,0 & 50 & 100 & & \\
\hline \multicolumn{9}{|l|}{ Pendidikan Ibu } \\
\hline Pendidikan Dasar $<9$ Tahun & 10 & 23,8 & 32 & 76,2 & 42 & 100 & \multirow{2}{*}{$\begin{array}{c}0,540 \\
(0,192-1,508)\end{array}$} & \multirow[t]{2}{*}{0,357} \\
\hline Pendidikan lanjut $>9$ Tahun & 11 & 36,7 & 19 & 63,3 & 30 & 100 & & \\
\hline
\end{tabular}

Beberapa penelitian menyatakan bahwa terdapat hubungan antara pemberian ASI dengan lamanya periode bayi menderita penyakit infeksi. Adanya kekebalan tubuh yang didapat dari ASI, membuat bayi walaupun terserang sakit tapi cepat sembuh dan membentuk kekebalan tubuh alami karena masuknya bakteri atau virus ke dalam tubuhnya (11); (8); (12). Anak yang mendapatkan ASI eksklusif mempunyai status gizi yang lebih baik dari pada ASI parsial atau yang diberi makanan atau minuman tambahan $<6$ bulan dan tidak pernah mendapatkan ASI. Pemberian ASI Eksklusif memiliki hubungan dengan kejadian gizi kurang pada balita (13) . Hal ini ditunjukkan dengan nilai signifikansi dari hasil pengolahan data dimana anak berumur 1-5 tahun dengan pemberian ASI yang tidak eksklusif lebih berisiko akan mengalami gizi kurang 7 kali lipat (14); (13). Bayi yang mendapat ASI cenderung memiliki frekuensi sakit dan periode lama sakit lebih rendah dibandingkan dengan bayi yang tidak diberi ASI ekslusif pada bayi dengan frekuensi sakit dan periode lama sakit yang rendah maka bayi dapat sehat sehingga nutrisi dapat terserap dengan baik ke dalam tubuhnya, sehingga balita memiliki status gizi yang baik seimbang antara berat dan tinggi badan (15); (16).

Pada penelitian ini, tidak ada hubungan riwayat imunisasi dengan status gizi baduta, sejalan dengan penelitian lainnya yang menyatakan tidak ada hubungan pemberian imunisasi dengan status gizi anak. Nilai korelasi ke arah negatif dan menunjukan keeratan hubungan yang lemah ( $\mathrm{r}=-$ 0,016 ), bahwa imunisasi salah satunya memberi kekebalan, tetapi jika tidak dibarengi dengan asupan nutrisi yang adekuat maka akan mudah anak mengalami penyakit infeksi (12). 
Berdasarkan hasil uji statistik diperoleh nilai $p$ value 1,000 >0,05 yang artinya tidak ada hubungan jumlah anak atau paritas dengan status gizi balita. Jumlah keluarga merupakan variabel penting dalam menganalisis gizi, karena jumlah anak dalam rumah tangga mempengaruhi sumber daya yang tersedia, jumlah anak yang lebih besar dapat meningkatkan pajanan infeksi yang mempengaruhi gizi buruk pada anak, serta ibu mengalami kesulitan dalam membagi waktu dalam mengurus anak terutama jika ada salah satu anak yang sakit (5). Berdasarkan penelitian lainnya (17) memiliki anak terlalu banyak menyebabkan kasih sayang pada anak terbagi. Kondisi ini akan memburuk jika status ekonomi keluarga tergolong rendah sumber daya yang terbatas, termasuk bahan makanan harus dibagi rata kepada semua anak. Hal ini sejalan dengan penelitian yang dilakukan oleh Gulo, dkk (18) dapat disimpulkan bahwa tidak terdapat hubungan antara jumlah anak dalam keluarga dengan kejadian gizi balita dengan p-value 0,729 sehingga jumlah anak dalam keluarga tidak berhubungan dengan masalah gizi.

Beberapa faktor penyebab jumlah anak dalam keluarga tidak ada hubungan dengan status gizi balita antara lain dikarenakan sebagian besar ibu bekerja sebagai ibu rumah tangga dan sangat memiliki waktu luang untuk ngurus anak-anak di rumah, walaupun pada penelitian ini tidak di identifikasi pekerjaan ibu, tetapi hasil penelitian lain mengatakan ibu yang memiliki banyak waktu untuk mengurus kebersihan di rumah walaupun anaknya lebih dari dua orang, maka ibupun memiliki banyak waktu untuk menyediakan makanan bagi anakanaknya, ibu sudah memiliki pengalaman yang baik dalam mengurus anak, faktor lainnya yaitu ibu memiliki anak yang telah dewasa yang mampu dalam mencukupi perekonomian keluarga, sehingga ibu tidak terbebani dalam mengurus anak-anak walupun anak berjumlah 3,4,5 atau bahkan lebih (19).

Demikian juga tidak ada hubungan pendidikan ibu dengan status gizi baduta. Menurut penelitian lainnya (20) pendidikan yang tinggi belum tentu menjamin ibu untuk berperilaku baik terkait pengelolaan asupan gizi balita. Ibu yang berpendidikan tinggi maupun rendah, saling mempunyai kesempatan dalam mendapatkan informasi dan pengetahuan yang baik untuk menunjang perilaku kesehatan dan status gizi balita. Kemajuan teknologi dan informasi saat ini memungkinkan ibu-ibu dalam mengakses informasi seputar kesehatan gizi, bahkan dapat langsung melakukan konseling atau mendapatkan informasi melalui kegiatan di posyandu, melalui para kader, bidan, atau di lingkungan setempat seperti keluarga dan tetangga. Oleh karena itu, pendidikan formal orang tua bukan lagi sebagai faktor penentu terhadap ibu atau kepala keluarga dalam meningkatkan pengetahuannya.

\section{KESIMPULAN DAN SARAN}

Hasil penelitian dari 72 subyek terdapat baduta gizi kurang $(29,2 \%)$ dan persentase tertinggi untuk riwayat asi ekslusif (56,9\%), mendapatkan imunisasi lengkap $(80,6 \%)$, paritas $<3$ orang anak $(69,9 \%)$. Ibu pendidikan dasar $<9$ tahun $(58,3 \%)$. Ada hubungan riwayat pemberian ASI Ekslusif dengan status gizi baduta dimana nilai $\rho(0,020<0,05)$, dan tidak ada hubungan riwayat imunisasi, paritas dan pendidikan ibu dengan status gizi baduta, dimana nilai $\rho>0,05$. Nilai PR 4,000 pada ASI ekslusif dengan status gizi baduta, artinya baduta yang tidak ASI ekslusif beresiko 4 kali lebih besar untuk mengalami status gizi kurang dibanding baduta yang mendapatkan ASI ekslusif. Penelitian selanjutnya dapat digunakan beberapa variabel lainnya dari kesehatan ibu selama hamil, misalnya status gizi ibu, pekerjaan ibu dan konsumsi obat cacing, karena faktor kesehatan ibu saat hamil menentukan berat bayi saat lahir, dan ini mempengaruhi status gizi bayi sampai usia di atas 6 bulan.

\section{UCAPAN TERIMAKASIH}

Penulis mengucapkan terimakasih atas dukungan Poltekkes Kemenkes Palangka Raya, melalui Direktur, wadir I,II, dan III yang sudah mendukung dan memfasilitasi. Terima kasih kepada Dinas Kesehatan Kota Palangka Raya dan Puskesmas Pahandut yang telah bekerjasama sampai kegiatan ini berjalan lancar, Serta ibu dari subyek penelitian dan semua pihak yang mendukung penelitian ini.

\section{DAFTAR PUSTAKA}

1. Dinkes Provinsi Kalimantan Tengah. Dinas kesehatan provinsi kalimantan tengah 2019. Profil Kesehat Provinsi Kalimantan Teng [Internet]. 2019;(09):1-251. Available from: http://www.dinkes.kalteng.go.id/

2. Dinas Kesehatan Kota Palangka Raya. Profil Kesehatan Kota Palangkaraya Tahun 2019. Persepsi Masy Terhadap Perawatan Ortod Yang Dilakukan Oleh Pihak Non Prof. 2013;53(9):168999.

3. Malika U, Raharja P, Waryana W, Sitasari A, Gizi J, Yogyakarta PK. Status ekonomi orang tua dan ketahanan pangan keluarga sebagai faktor risiko stunting pada balita di Desa Bejiharjo The 
economic status of parents and family food security as a risk factor for stunting. 2019;03(01):73-82.

4. Bahu R, Hasania E, Hilamuhu F. Hubungan Paritas Dan Dukungan Suami Dengan Rendahnya Minat Penggunaan Alat Kontrasepsi Metode Tubektomi Di Puskesmas Tibawa. Akad J Ilm Media Publ Ilmu Pengetah dan Teknol. 2019;8(1):67.

5. Rosadi D, Rahayuh A, Yulidasari F, Putri AO, Rahman F. Faktor Risiko Yang Berhubungan Dengan Kejadian Pendek Pada Anak Usia 6-24 Bulan. J Kesehat Masy. 2016;11(2):233.

6. Wayan N, Asthiningsih W, Muflihatin SK. DETEKSI DINI PERKEMBANGAN BALITA DENGAN METODE. 2018;3(2):367-74.

7. Rosha BC, Sari K, SP IY, Amaliah N, Utami N. Peran Intervensi Gizi Spesifik dan Sensitif dalam Perbaikan Masalah Gizi Balita di Kota Bogor. Bul Penelit Kesehat. 2016;44(2):127-38.

8. Kasim E, Malonda N, Amisi M. Hubungan Antara Riwayat Pemberian Imunisasi dan Penyakit Infeksi dengan Status Gizi pada Anak Usia 24-59 Bulan di Kecamatan Ratahan Kabupaten Minahasa Tenggara. (Relationship Between History of Immunization and Infectious Disease with Nutritional Status i. J Bios Logos. 2019;9(1):34.

9. Aridiyah FO, Rohmawati N, Ririanty M. Faktorfaktor yang Mempengaruhi Kejadian Stunting pada Anak Balita di Wilayah Pedesaan dan Perkotaan ( The Factors Affecting Stunting on Toddlers in Rural and Urban Areas ). e-Jurnal Pustaka Kesehat. 2015;3(1).

10. Muniroh L, Ni'mah C. Hubungan tingkat pendidikan, tingkat pengetahuan dan pola asuh ibu dengan. Media Gizi Indones. 2015;10, No 1:84-90.

11. Irawan J. Hubungan Inisiasi Menyusu Dini ( IMD ) dan pemberian Air Susu Ibu ( ASI ) Eksklusif DI RSUD Wangaya. Skala Husada [Internet]. 2018;15(1):1-7. Available from: http:/ / ejournal.poltekkes-

denpasar.ac.id/index.php/JSH/article/downloa $\mathrm{d} / 218 / 89$

12. Masyarakat JK. Hubungan Karakteristik Ibu, Pola Asuh Dan Pemberian Imunisasi Dasar Terhadap Status Gizi Anak Usia 12-24 Bulan (Studi Di Wilayah Kerja Puskesmas Kedungmundu Kota Semarang Tahun 2017). J Kesehat Masy. 2017;5(4):788-800.

13. Andriani $R$, Wismaningsih ER, Indrasari $O R$. Hubungan Pemberian Asi Eksklusif Dengan Kejadian Status Gizi Kurang Pada Balita Umur 1 - 5 Tahun Correlation Between Exclusive Breastfeeding Provision With Toddler ' S Malnutrition Status Age 1 - 5 Years Old. J
Wiyata. 2015;2(No 1):44-7.

14. Andriani R, Wismaningsih ER, Indrasari OR. Hubungan Pemberian ASI EKSKLUSIF Dengan Kejadian Status Gizi Kurang Pada Balita Umur 1 - 5 Tahun. 2015;44-7.

15. Desa DJP dan PM. Panduan Fasilitasi Konvergensi Pencegahan Stunting di Desa. Jakarta: Direktorat Jenderal Pembangunan dan Pemberdayaan Masyarakat Desa; 2018.

16. Migang YW, Rarome MJ, Heriteluna M, Dawam M. Intervention of Specific Nutrition and Sensitive Nutrition with Nutritional Status of Under Two-Year Infants in Family Planning Village as Efforts to Face the Demographic Bonus. J Kesehat Masy [Internet]. 2020 Jul 27;16(1):101-10. Available from: http://journal.unnes.ac.id/nju/index.php/kema s\%0AIntervention

17. Septiana R, Djannah SN, Djamil MD. Hubungan Antara Pola Pemberian Makanan Pendamping Asi (Mp-Asi) Dan Status Gizi Balita Usia 6-24 Bulan Di Wilayah Kerja Puskesmas Gedongtengen Yogyakarta. J Kesehat Masy (Journal Public Heal. 2014;4(2):118-24.

18. Gulo HH, Evawany, Jumirah. Hubungan Karakteristik Keluarga Dengan Kasus Balita Gizi Buruk Pada Keluarga Petani Karet Di Wilayah Binaan Wahana Visi Indonesia Area Development Program Kabupaten Nias Tahun 2013. 2013;32(7):1-33.

19. Karundeng LR, Ismanto YA, Kundre R. Hubungan Jarak Kelahiran Dan Jumlah Anak Dengan Status Gizi Balita Di Puskesmas Kao Kecamatan Kao Kabupaten Halmahera Utara. J Keperawatan UNSRAT. 2015;3(1):114321.

20. Miko A, Hendra A. Hubungan Berat Dan Tinggi Badan Orang Tua Dengan Status Gizi Balita Di Kabupaten Aceh Besar. Gizi Indones. 2017;40(1):21. 